Bangladesh J. Bot. 48(1): 75-84, 2019 (March)

\title{
EFFECTS OF SOWING DATES AND MULCHING ON GROWTH AND YIELD OF WHEAT AND WEEDS (PHALARIS MINOR RETZ.)
}

\author{
Manoj Kumar Singh*, Amit Mishra, Naveen Khanal \\ and Saroj Kumar Prasad \\ Department of Agronomy, Institute of Agricultural Sciences, Banaras Hindu University, \\ Varanasi (U.P.) 221005, India
}

Keywords: Late sowing, Mulching, Weed infestation, Wheat productivity, Phalaris minor

\begin{abstract}
Weed infestation, particularly Phalaris minor Retz. is a serious threat for increasing wheat productivity in Indo-Gangetic Plains of India. The primary objective of this research was to study the effect of sowing dates and mulching on the growth of wheat and weeds. In general, early sowing (November-25) exhibited less growth of $P$. minor, but increased weed biomass and lower wheat yields than the delayed (December-10) sowing date. Application of paddy straw, jute mat, and black polythene mulches positively increased the height, tiller count, yield of wheat; and drastically reduced weed infestation, especially the growth of $P$. minor. Moreover, under no weed management, delayed sowing increased the wheat yield, over earlier sowing. It was concluded that organic mulches can sustainably manage the weed infestation, particularly P. minor and increase the wheat yield.
\end{abstract}

\section{Introduction}

In India, wheat is a staple cereal grown in an area of 30.22 million ha with an annual production and productivity of $98.38 \mathrm{Mt}$ and $3.0 \mathrm{t} / \mathrm{ha}$, respectively (GoI 2017). In fact, it is an important source of nutrition for about $40 \%$ of the population (Joshi et al. 2010). To fulfill the demand of the burgeoning Indian population, it is estimated that by 2051 A.D., wheat production needs to increase by $110-120 \mathrm{M}$ tons. By that time, however, it is expected that the area under wheat production would decrease by 5-6 M ha. Thus, average wheat productivity needs to increase up to 5 t/ha to feed the population (Sharma et al. 2013).

Exacerbating weed problem accounts for 20-40 per cent reduction in wheat yield (Sharma 2009). Among weeds, Phalaris minor predominates in wheat-growing regions of Indian subcontinent (Singh 2007) and has potential to reduce yield by 80 per cent (Singh et al. 1999). Therefore, for sustaining the wheat grain production, weed management is very essential. Herbicides, while effective, are not widely used by farmers, specially in eastern Indo-Gangetic Plains of Uttar Pradesh, due to technological and socio-economic constraints (Singh 2011).

Keeping the above fact in view, 'sowing date' and 'mulching' were tested as potential nonchemical approach for weed management. In fact, altering the sowing dates influences the weed communities (Milberg et al. 2001), and provides a competitive advantage in yielding the crop (Singh et al. 1995, Singh and Saini 2008). Furthermore, greater interests have developed recently in the utilization of mulch for crop production. Organic mulch materials, such as paddy straw, carpet waste and jute mat are abundantly available in the eastern Uttar Pradesh. Indeed, 95 per cent of global jute is produced in India, Bangladesh, China, Nepal and Thailand (Maity et al. 2012). Organic mulching improves the physical, chemical, biological properties of soil (Kasirajan and Ngouajio 2012), and also controls weeds (Singh and Saini 2008, Anzalone et al. 2010), pests

*Author for correspondence: <manoj.agro@bhu.ac.in>, <manozsingh@ rediffmail.com>. 
and diseases (Hu et al. 1995) besides its positive influence on crop yield (Singh and Saini 2008, Anzalone et al. 2010). Though, nowadays plastic mulches are used in large volume in commercial crop production (Bhardwaj 2013). The plastic mulch materials, such as poly vinyl chloride or polyethylene films, have been successfully used for weed control and enhancement of crop yield in many crops (Campiglia et al. 2010, Waterer 2010).

The aim of this work was to find out the effect of sowing dates, organic and inorganic mulch application and on performance of wheat and weeds in general, and $P$. minor in particular.

\section{Materials and Methods}

The field trial was carried out at the Agricultural Research Farm, Institute of Agricultural Sciences, Banaras Hindu University, Varanasi, India (128.93 m above mean sea level, $25^{\circ} 18^{\prime} \mathrm{N}$, $83^{0} 30^{\prime} \mathrm{E}$ ), at same site and plots, for three consecutive winter seasons from 2008-2009, 2009-2010 and 2010-2011. Soil was sandy clay loam (Typic Ustochrept; Order Inceptisol) with $0.43 \%$ organic C, $\mathrm{pH} 7.10$, low in available $\mathrm{N}(196.5 \mathrm{~kg} / \mathrm{ha})$, and medium in available $\mathrm{P}(25.7 \mathrm{~kg}$ $\left.\mathrm{P}_{2} \mathrm{O}_{5} / \mathrm{ha}\right)$ and $\mathrm{K}(220.0 \mathrm{~kg} \mathrm{~K} \mathrm{O} / \mathrm{ha})$. During the three years of experimentation, the average maximum and minimum temperature was found to range between $20.5-38.7^{\circ} \mathrm{C}$ and $9.2-22.1^{\circ} \mathrm{C}$, respectively.

The experiment was laid out in the split plot design with 3 replications. Keeping two sowing dates (November 25 and December 10) were assigned in the main plots, while six mulch treatments [no-mulch, paddy straw 6 t/ha (dry weight basis), carpet waste 6 t/ha (dry weight basis), jute mat, black polyethelene ( $2 \mathrm{~mm}$ sheet), white clear polyethelene $(2 \mathrm{~mm}$ sheet $)$ ] were in subplots. In 5.0 by $3.0 \mathrm{~m}$ plots, wheat (variety: HUW-468) was sown at $22 \mathrm{~cm}$ row spacing with 100 $\mathrm{kg}$ seed/ha. Mulches were applied immediately after sowing. The rest of the field operations were carried out as per standard agronomic practices.

Plant height and length of panicle were measured from five randomly selected plants. At physiological maturity, grain and straw yield were recorded and expressed in $\mathrm{kg} / \mathrm{ha}$. Test weight (1000-seed weight) was estimated by randomly counting P. minor seeds and wheat grains from the bulk produce of every plot and weighed. Tiller count of wheat was recorded from two spots, each of $50 \mathrm{~cm}$ row length, per plot and presented in number $/ \mathrm{m}^{2}$. In $P$. minor, parameter like, biomass, number of tillers, panicle count and leaf area were estimated from $0.25 \mathrm{~m}^{2}$ area from each plot. Leaf area index was calculated as per the formula prescribed by Watson (1952). Seed count was calculated by threshing five randomly sampled panicles and the number of seed/panicle was counted. Weed density was recorded on January 25 (i.e. critical stage of crop-weed competition) as per the procedure mentioned by Singh and Saini (2008).

Bartlett's test was used to test the homogeneity of variance among treatments. Heterogeneous weed data i.e. total weed (density and biomass) and $P$. minor biomass were square-root transformed prior to the analysis to produce a near normal distribution, although non transformed means are presented for clarity. After testing for homogeneity, all data were put to analysis of variance (ANOVA) as described by Gomez and Gomez (1984). The mean separation was accomplished by least significant difference (LSD) at 5\% level of probability. ANOVA results indicated that there were no significant interactions between treatments and experimental years for most of the parameters recorded, thus, the data were pooled for combined analysis.

\section{Results and Discussion}

In wheat, observation recorded on January- 25 showed, a significant higher plant height under the November-25 date of sowing (DoS hereafter) as compared to the December-10 DoS; but at the harvest, the difference was non-significant $(\mathrm{p}<0.05)$ (Table 1$)$. In fact, on the January 25, wheat 
crop sown on November-25 DoS was at late tillering/terminal spikelet stage, whereas the December-10 sown crop was at crown root initiation stage and was 15 days younger than the November-25 sown crop. So, obviously, by virtue of the age, November-25 sown crop had taller plant height over the December-10 sown crop. On the other hand, however, December-10 DoS produced a higher tiller count and grain yield over November- 25 sown crop. Length of panicle, 1000 -seed weight and straw yield differed non-significantly, with the difference in DoS.

Furthermore, January-25 observation revealed that November-25 sown crop increased the density and biomass of the weed as compared to later sowing date i.e. December-10 DoS (Table 2). P. minor grown under November- 25 sown crop showed higher plant height, biomass, leaf area index, tiller count and panicle count as compared to the December-10 DoS (Table 2). LAI on January 25, length of panicle, seed count, 1000-seed weight, seed and straw yield (Table 3) did not differ significantly with the difference of DoS.

Higher number of tiller and grain yield of wheat recorded at the December-10 DoS are ascribed due to the fact that this timing coincided with low temperatures that caused the poor germination and growth of weeds in general, $P$. minor in particular, thus favoring the competitive advantage to the crop. Earlier findings also demonstrated successive decrease in weed infestations and their dry biomass under delayed sowing from normal (20,30 November) to mid-late $(5,15$ December) or late (20, 30 December) sowing (Kurchania et al. 1993). Indeed, an ideal temperature required for the germination of $P$. minor is $17-20^{\circ} \mathrm{C}$ (Singh and Ghosh 1982). In November, the minimum ambient temperature was $16^{\circ} \mathrm{C}$, whereas in December the minimum temperature was below $11^{\circ} \mathrm{C}$, and this lower temperature continues till January. Thus, lower temperature not only hampered the germination of $P$. minor, but also negatively influenced its growth, viz. plant height, biomass, LAI, and number of tiller.

Kolar and Mehra (1992) also observed a higher biomass in P. minor in November sowing compared to that of October or the December sowing. Furthermore, the data clearly indicated that November-25 sowing (because of the higher number of panicles) had higher chances of seed production over later DoS.

In fact, previous findings also reveal that substantial wheat area, specially in eastern Uttar Pradesh, suffers from terminal heat stress firstly due to delayed sowing of long duration paddy varieties in rice-wheat cropping areas (Joshi et al. 2007) and secondly, because of the climate change and its results in shorter winters as well as the onset of significantly higher temperatures much earlier than normal (Joshi et al. 2007a). This could result in a reduced grain yield. The present findings also showed a lower yield under both the late sowing conditions as compared to the previously reported yield of the normal sown crop (Hussain et al. 2012). In addition, the present finding supplements the previous experimental facts that linear reduction of wheat yield under delayed sowing after October 25 (Hussain et al. 2012), could only be noticed when weeds are properly taken care of. However, if weeds are not properly managed, more yield loss can be observed under early late sowing (November-25) as compared to sowing (December-10) of wheat.

Both plant height and tiller count did not differ significantly during the January-25 observation $(\mathrm{p}<0.05)$ (Table 1). Even, at the harvest, plant height and number of tiller showed similar result with all the tested mulch treatments, except for the carpet waste mulch. Application of the carpet waste noticeably produced lowest plant height. Furthermore, application of the carpet waste mulch produced a longest panicle length and was statistically at par with the jute mat. Contrary to panicle length, the lowest 1000 -seed weight was recorded under the carpet waste mulch and was statistically at per with paddy straw mulch; though jute mat mulch recorded the highest 1000-grain weight. Statistically similar higher wheat grain yield was recorded under the 


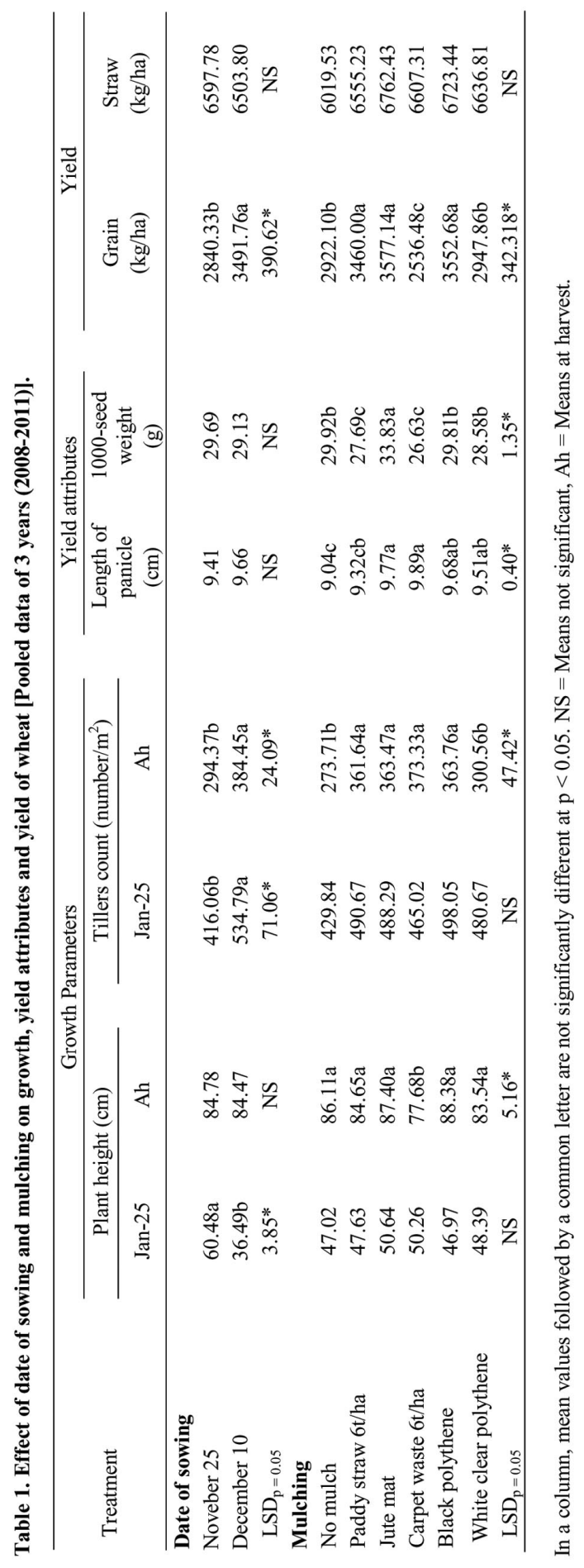




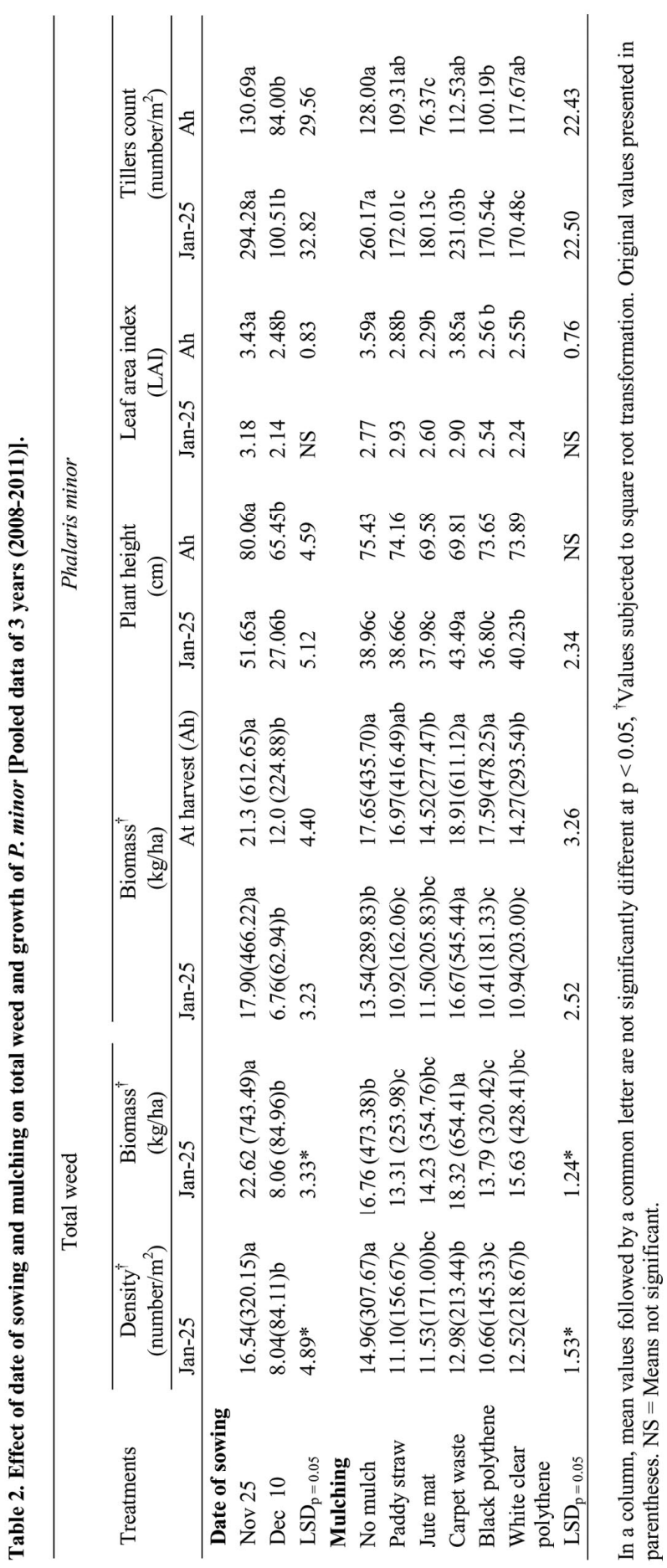


jute mat, black polyethelene and paddy straw mulches; whereas the lowest grain yield was recorded under the carpet waste mulch followed by the white clear polyethelene mulch and nomulch.

The black polyethelene, paddy straw and jute mat mulches produced the lower density and -biomass of total weeds. However, higher density and biomass were produced by no-mulch and the carpet waste mulch (Table 2). In case of P. minor, observation on January-25 showed significantly highest plant height under the carpet waste mulch, followed by the white clear polyethelene mulch (Table 2). However, plant height did not differ significantly at the harvest ( $\mathrm{p}<$ 0.05). Furthermore, almost similar lower plant height and biomass were recorded, at the initial stage, under the black polyethelene, paddy straw and jute mat mulches. LAI did not differ significantly during the initial observation on January 25. But at the harvest, the highest LAI was recorded under the carpet waste and was statistically at par with no-mulch; while the rest of the treatment showed statistically at par results. Observation recorded on January 25 showed the highest number of tillers under no-mulch, followed by the carpet waste; rest of treatment showed statistically similar lower number of tillers. At harvest, the highest number of tillers was observed under no-mulch and the lowest number of tillers count was however, recorded under the jute mat mulch.

Table 3. Effect of date of sowing and mulching on yield attributes and yield of $P$. minor [Pooled data of 3 years $(2008-2011)]$.

\begin{tabular}{|c|c|c|c|c|c|c|}
\hline Treatments & $\begin{array}{l}\text { Panicles } \\
\text { count } \\
\left(\mathrm{No} . \mathrm{m}^{2}\right)\end{array}$ & $\begin{array}{l}\text { Length of } \\
\text { panicle } \\
(\mathrm{cm})\end{array}$ & $\begin{array}{l}\text { Seed count } \\
\text { (No./panicle) }\end{array}$ & $\begin{array}{l}\text { 1000-seed } \\
\text { weight } \\
\text { (g) }\end{array}$ & $\begin{array}{l}\text { Seed } \\
(\mathrm{kg} / \mathrm{ha})\end{array}$ & $\begin{array}{l}\text { Straw } \\
(\mathrm{kg} / \mathrm{ha})\end{array}$ \\
\hline \multicolumn{7}{|l|}{ Date of sowing } \\
\hline Nov 25 & $143.78 \mathrm{a}$ & 4.78 & 84.68 & 1.40 & 257.18 & 641.04 \\
\hline Dec 10 & $118.89 \mathrm{~b}$ & 4.44 & 86.79 & 1.39 & 288.94 & 630.44 \\
\hline $\mathrm{LSD}_{\mathrm{p}=0.05}$ & $7.44^{*}$ & NS & NS & NS & NS & NS \\
\hline \multicolumn{7}{|l|}{ Mulching } \\
\hline No mulch & $158.17 \mathrm{a}$ & $4.68 \mathrm{a}$ & $82.95 b$ & $1.31 \mathrm{~b}$ & $292.96 a$ & $567.49 \mathrm{dc}$ \\
\hline Paddy straw@6t/ha & $151.33 b$ & $4.61 \mathrm{a}$ & $81.46 \mathrm{~b}$ & $1.39 \mathrm{~b}$ & $289.64 a$ & $851.81 \mathrm{a}$ \\
\hline Jute mat & $114.83 \mathrm{e}$ & $4.79 \mathrm{a}$ & $86.98 b$ & $1.42 \mathrm{~b}$ & 264.19ab & $664.94 b$ \\
\hline Carpet waste @6t/ha & $133.33 \mathrm{c}$ & $4.84 \mathrm{a}$ & $100.32 \mathrm{a}$ & $1.60 \mathrm{a}$ & $240.18 b$ & $626.68 b c$ \\
\hline Black polythene & $122.58 \mathrm{~d}$ & $4.24 b$ & $65.48 \mathrm{c}$ & $1.36 b$ & $270.56 \mathrm{ab}$ & $511.88 d$ \\
\hline White clear polythene & $108.08 \mathrm{f}$ & $4.54 \mathrm{ab}$ & $97.24 \mathrm{a}$ & $1.31 \mathrm{~b}$ & $280.81 \mathrm{a}$ & $591.65 b$ \\
\hline $\mathrm{LSD}_{\mathrm{p}=0.05}$ & $5.18 *$ & $0.33^{*}$ & $6.48 *$ & $0.13^{*}$ & $33.97 *$ & $95.02 *$ \\
\hline
\end{tabular}

In a column, mean values followed by a common letter are not significantly different at $\mathrm{p}<0.05$.

NS = Means not significant.

Significantly the lowest number of panicle $/ \mathrm{m}^{2}$ was recorded under the white clear polyethelene mulch, followed by the jute mat and black polyethelene mulch (Table 3). Smallest length of panicle was recorded under the black polyethelene and was statistically at par with white clear polyethelene mulch. The black polyethelene mulch produced the lowest number of seed, followed by paddy straw no-mulch and jute mat mulch and the highest 1000-seed weight was recorded under the carpet waste. Significantly the highest 1000 -seed weight was recorded under the carpet waste mulch; the rest of the treatments showed statistically similar results. The lowest seed yield was recorded under the carpet waste, followed by the jute mat and black polyethelene 
mulch; whereas the highest seed yield was recorded under no-mulch which are statistically at per with paddy straw, and white clear polyethelene mulch. The lowest straw yield was observed under the black polyethelene mulch; whereas the highest straw yield was recorded under paddy straw mulch.

Application of the carpet waste mulch produced the lower plant height, length of panicle and grain yield. This could be attributed to lower the C : N ratio (Shekhawat et al. 2010); it gets readily decomposed and adds nitrogen to the soil through mineralization. Rapid mineralization of nitrogen and other nutrient shifts the balance of crop-weed competition in favor of weeds, thereby resulting in increased density and biomass of weeds in general and $P$. minor in particular. Another reason could be due to the poor partitioning of photosynthate from the vegetative part to the reproductive organs which leads to lower production of $P$. minor seeds. Application of the paddy straw, jute mat and black plastic effectively suppressed the weeds; at the same time, enhanced wheat growth and yield. One of the most common reasons for reduced infestation under the black polyethelene, paddy straw, jute mat and white clear polyethelene mulch could be attributed to better cover of ground surface, as it reduces the entry of light to the soil surface, thus inhibiting the germination of photoblastic seeds. Similar effects of straw mulch on weed growth are also observed by Singh and Saini (2008) in Japanese mint. Besides, previous studies also showed weed growth suppression under straw mulching due to one or combinations of reasons, viz., the effect of light transmittance, soil temperature and soil moisture (Teasdale 1993); release of allelochemicals by decomposed straw (Liebman and Davis 2000, Weston 1996); mechanical hindrance or direct suppression of the emerging weeds (Dyck and Liebman 1994); reduced N-availability (Siebert and Pearce 1993); or weed seed predation (Reader 1991). Similarly, reduced light transmission plays a pivotal role in suppression of weed growth under the fabric mat mulch (Miao et al. 2013). Moreover, reasons for weed suppression and higher crop yield under the plastic mulch can be attributed to the twin effect of reduced light penetration (Upadhyaya and Blackshaw 2007) and increased soil temperature (Moreno et al. 2009). Most often, clear and dark colour mulches increase more temperature over reflective colour mulches (Moreno et al., 2009). The similar postitive effect of the black plastic and paddy straw mulch on the yield of tomato was observed by Moreno et al. (2009) and Anzalone et al. (2010). Niu et al. (1998) also reported that the plastic film mulches increased dry matter accumulation in the early stage and dry matter mobilization from vegetative tissues after anthesis increasing the grain yield. Furthermore, the jute mat mulch being resistant to decomposition (decomposes in 2 - 3 years) (Maiti 2013) effectively covers the ground surface and suppresses the growth of weeds due to combinations of reasons as mentioned in the straw mulching. Application of the jute mat mulch has added advantage that it is safe, biodegradable, non-toxic to both soil and plant (Maiti 2013) and is easily applied in the field. Higher P. minor seed yield under the paddy straw and the jute mat mulches might be due to higher length of the panicle, whereas higher seed yield under white clear polyethelene might be due to higher length of the panicle and seed count/panicle.

Experimental results normally reveal that polythene mulches are more effective in suppressing weeds and increasing the yield of crop over straw mulch (Anzalone et al. 2010). But the present results show that in most of the parameters they are comparable to the paddy straw and jute mat mulches. Reasons for this might be, in most of plastic mulching experiments, plastic films were laid on the soil surface and the edges were closed tightly with soil. Then, holes were drilled by a bar (Xie et al. 2005). After the seedling emergence, the film was cut along the row to allow the normal growth of plants ( $\mathrm{Li}$ et al. 1999). This method is applicable in vegetable production, where seedlings are transplanted. But, in this experiment, as wheat was directly sown in the field, thus strips of plastic film were laid in between the inter-row spaces. To check its displacement and to keep it intact on the surface, plastic mulch was fasted with iron clip (like stapler pins) and their 
edges were not tightly sealed in the soil. This would result in less increments in temperature under the sheet and weeds on the edges of the sheet are not well managed. It is worthwhile to mention that laying of plastic mulch and keeping it intact on the ground surface is a tedious job, which pave the way to the agricultural engineer to device modification in agricultural machinery for laying of plastic films in the inter-row spaces. However, further research needs to be carried out to verify similar response under other sources and differential rates of mulch on crop growth and weeds.

In summary, under the Indo-Gangetic Plains of eastern Uttar Pradesh, early sowing (November-25) of wheat provided conducive environment for infestation of weeds and had a positive influence on vegetative growth of $P$. minor; in contrast late sowing (December-10) resulted in lower weed infestation and had a positive influence on wheat growth and yield. Application of organic mulches, such as paddy straw mulch $6 \mathrm{t} / \mathrm{ha}$ and jute mat mulch effectively suppress weed growth in general and $P$. minor in particular (especially during critical period of crop-weed competition) and at the same time enhanced wheat growth (plant height, tiller count) and produced a higher length of panicle and grain yield. Carpet waste mulch was found to be highly ineffective in suppression of weeds and produced a poor grain yield of wheat. Black as well as white clear polyethelene were effective in suppression of total weeds and vegetative growth of $P$. minor, but increase $P$. minor seed yield.

\section{Acknowledgments}

The authors would like to acknowledge the financial assistance provided by Council of Science and Technology, Uttar Pradesh (CST UP) for the project. They also gratefully acknowledge Dr. P. Dalai, Department of English, Banaras Hindu University, Varanasi for proofreading of the article.

\section{References}

Anzalone A, Cirujeda A, Aibar J, Pardo G and Zaragoza C 2010. Effect of biodegradable mulch materials on weed control in processing tomatoes. Weed Technol. 24: 369-377.

Bhardwaj RL 2013. Effect of mulching on crop production under rainfed condition - A review. Agric. Rev. 34: 188-197.

Campiglia E, Caporali F, Radicetti E and Mancinelli R 2010. Hairy vetch (Vicia villosa Roth.) cover crop residue management for improving weed control and yield in no-tillage tomato (Lycopersicon esculentum Mill.) production. Eur. J. Agron. 33: 94-102.

Dyck E and Leibman M 1994.Soil fertility management as a factor in weed control, the effect of crimson clover residue, synthetic nitrogen fertilizer and their interactions on emergence and early growth of lambsquarters and sweet corn. Plant Soil. 167: 227-237.

GoI 2017. Agricultural Statistics at a Glance 2016. Government of India, Ministry of Agriculture and Farmers Welfare, Department of Agriculture, Cooperation \& Farmers Welfare, India.

Gomez KA and Gomez AA 1984. Statistical Procedures in Agricultural Research, $2^{\text {nd }}$ Edition. New York (NY): Wiley.

Hu W, Duan S and Sui Q 1995. High yield technology for groundnut. Int. Arachis Newslett. 15: 1-22.

Hussain M, Farooq M, Shabir G, Khan MB, Zia AB and Lee DJ 2012. Delay in planting decreases wheat productivity. Int. J. Agric. Biol. 14: 533-539.

Joshi AK, Chand R, Arun B, Singh RP and Ortiz R 2007. Breeding crops for reduced-tillage management in the intensive, rice-wheat systems of South Asia. Euphytica. 153: 135-151.

Joshi AK, Crossa J, Arun B, Chand R, Trethowan R, Vargas M and Ortiz-Monasterio I 2010. Genotype $\times$ environment interaction for zinc and iron concentration of wheat grain in eastern Gangetic Plains of India. Field Crop Res. 116: 268-277. 
Joshi AK, Mishra B, Chatrath R, Ortiz Ferrara G and Singh RP 2007a. Wheat improvement in India: Present status, emerging challenges and future prospects. Euphytica. 157: 431-446.

Kasirajan S and Ngouajio M 2012. Polyethylene and biodegradable mulches for agricultural applications: a review. Agron. Sustain. Dev. 32: 501-529.

Kolar JS and Mehra SP 1992.Changing scenario of weed flora in agro-ecosystem of Punjab. In: Dhaliwal GS, Hansra BS and Jerath N, editors. Changing scenario of our environment. Ludhiana, India: Punjab Agricultural University. pp. 252-262.

Kurchania SP, Tiwari JP, Patel ML and Jain HC 1993. Effect of chemical weed control under different sowing dates and planting patterns of growth and sink potential of dwarf wheat (Triticum aestivum). Indian J. Agric. Sci.63: 591-593.

Li FM, Guo AH and Wei H 1999.Effects of clear plastic film mulch on yield of spring wheat. Field Crop Res. 63: 79-86.

Liebman M and Davis AS 2000. Integration of soil, crop, and weed management in low external input farming systems. Weed Res. 40: 27-47.

Maiti SK 2013.Ecorestoration of the coalmine degraded lands. New York, USA: Springer Press.

Maity S, Singha K, Gon DP, Paul P and Singha M 2012. A review on jute nonwovens: manufacturing, properties and applications. Int. J. Text. Sci.1: 36-43.

Miao M, Pierlot AP, Millington K, Gordon SG, Best A and Clarke M 2013.Biodegradable mulch fabric by surface fibrillation and entanglement of plant fibers. Text. Res. J.83: 1906-1917.

Milberg P, Hallgren E and Palmere MW 2001. Timing of disturbance and vegetation development: how sowing date affects the weed flora in spring-sown crops. J. Veg. Sci.12: 93-98.

Moreno MM, Moreno A and Mancebo I 2009. Comparison of different mulch materials in a tomato (Solanum lycopersicum L.) crop. Span. J. Agric. Res.7: 454-464.

Niu JY, Gan JW, Zhang JW and Yang QF 1998. Post-anthesis dry matter accumulation and redistribution in spring wheat mulched with plastic film. Crop Sci. 38: 1562-1568.

Reader RJ 1991. Control of seedling emergence by ground cover a potential mechanism involving seed predation. Can. J. Botany. 69: 2084-2087.

Seibert AC and Pearce RB 1993. Growth analysis of weed and crop species with reference to seed weight. Weed Sci. 41: 52-56.

Sharma I, Singh G, Tyagi BS and Sharma RK 2013. Wheat improvement in India - Achievement and future challenges. Paper presented at: All India Wheat and Barley Research Workers' Meet; Sep. 1-4; C. S. Azad University of Agriculture and Technology, Kanpur, India.

Sharma R 2009. Integrated weed management technologies in wheat. In: Sharma RK,Aggarwal S, Singh AM, Sharma A and Sharma JB, editors. Consolidating the Productivity Grain in Wheat-An Outlook. New Delhi, India: Indian Agricultural Research Institute; pp. 52-56.

Shekhawat BS, Singh Y, Singh SP, Meena RN, Singh Y and Singh K 2010. Utilization of industrial and farm waste with minerals and bio-activators for sustained productivity in eastern Uttar Pradesh. Indian J. Fert. 6: 36-40.

Singh M 2011. Yield gap and production constraints in rice-wheat system: scenario from eastern Uttar Pradesh. Bangladesh J. Agril. Res. 36: 623-632.

Singh MK and Saini SS 2008.Planting date, mulch, and herbicide rate effects on the growth, yield, and physicochemical properties of menthol mint (Mentha arvensis). Weed Technol. 22: 691-698.

Singh RD and Ghosh AK 1982. Soil profile distribution and effect of temperature and soil depth on germination of Phalaris minor Retz. In: Abstract, Annual Conference of Indian Society of Weed Science. Hissar, India: Indian Society of Weed Science. pp. 41-42.

Singh S 2007. Role of management practices on control of isoproturon-resistant littleseed canary grass (Phalaris minor) in India. Weed Technol. 21: 339-346.

Singh S, Kirkwood RC and Marshall G 1999. Biology and control of Phalaris minor Retz. (littleseed canary grass) in wheat. Crop Prot. 18: 1-16. 
Singh S, Malik RK, Panwar RS and Balyan RS 1995. Influence of sowing time on winter wild oat (Avena ludoviciana) control in wheat (Triticum aestivum) with isoproturon. Weed Sci. 43: 370-374.

Teasdale JR 1993. Interaction of light, soil moisture, and temperature with weed suppression by hairy vetch residue. Weed Sci. 41: 46-51.

Upadhyaya MK and Blackshaw RE 2007. Non-chemical Weed Management- Principles, Concepts and Technology. U.K.: CABI.

Waterer D 2010.Evaluation of biodegradable mulches for production of warm-season vegetable crops. Can. J. Plant Sci. 90:737-743.

Watson DJ 1952. The physiological basis of variation in yield. Adv. Agron. 4: 101-145.

Weston LA1996. Utilization of allelopathy for weed management in agro-ecosystems. Agron. J. 88: 860-866.

Xie Z, Wang Y and Li F 2005.Effect of plastic mulching on soil water use and spring wheat yield in arid region of northwest China. Agr. Water Manage. 75: 71-83.

(Manuscript received on 2 May, 2018; revised on 13 October, 2018) 